\title{
Amburana cearensis: Pharmacological and Neuroprotective Effects of Its Compounds
}

\author{
Juliana Helena Castro e Silva ${ }^{1}{ }^{(}$, Rafael Short Ferreira ${ }^{1}$ (), Erica Patricia Pereira ${ }^{1}(\mathbb{D}$, \\ Suzana Braga-de-Souza ${ }^{1}$, Monique Marylin Alves de Almeida ${ }^{1}{ }^{(\mathbb{O}}$, Cleonice Creusa dos Santos ${ }^{1}$, \\ Arthur Morgan Butt $\left.{ }^{2}{ }^{(}\right)$, Elisabetta Caiazzo ${ }^{3}\left(\mathbb{D}\right.$, Raffaele Capasso ${ }^{4, *} \mathbb{C D}^{\text {, }}$ \\ Victor Diogenes Amaral da Silva ${ }^{1, *}$ and Silvia Lima Costa ${ }^{1, *}$ \\ 1 Laboratory of Neurochemistry and Cell Biology, Department of Biochemistry and Biophysics, Institute of \\ Health Sciences, Federal University of Bahia, Av. Reitor Miguel Calmon s/n Vale do Canela, \\ 40100-902 Salvador, Bahia, Brazil; juhhmc@hotmail.com (J.H.C.eS.); rafael_short@hotmail.com (R.S.F.); \\ epereira229@gmail.com (E.P.P.); suzanabrasilia@uol.com.br (S.B.-d.-S.); \\ moniquemarylin27@gmail.com (M.M.A.d.A.); cleonicemev@gmail.com (C.C.d.S.) \\ 2 School of Pharmacy and Biomedical Sciences, University of Portsmouth, St Michael's Building, \\ White Swan Road, Portsmouth, Portsmouth PO1 2DT, UK; Arthur.butt@port.ac.uk \\ 3 Department of Pharmacy, University of Naples Federico II, Via D. Montesano 49, 80131 Naples, Italy; \\ elisabetta.caiazzo@unina.it \\ 4 Department of Agricultural Sciences, University of Naples Federico II, Via Università 100, 80055 Portici, Italy \\ * Correspondence: rafcapas@unina.it (R.C.); vdsilva@ufba.br (V.D.A.d.S.); costasl@ufba.br (S.L.C.); \\ Tel.: +39-081-678-664 (R.C.); +55-71-3283-8919 (V.D.A.d.S. \& S.L.C.)
}

Academic Editor: Derek McPhee

Received: 20 June 2020; Accepted: 23 July 2020; Published: 27 July 2020

\begin{abstract}
Amburana cearensis A.C. Smith is an endemic tree from Northeastern Brazil used in folk medicine as teas, decocts and syrups for the treatment of various respiratory and inflammatory diseases, since therapeutic properties have been attributed to compounds from its stem bark and seeds. Numerous pharmacological properties of semi-purified extracts and isolated compounds from $A$. cearensis have been described in several biological systems, ranging from antimicrobial to anti-inflammatory effects. Some of these activities are attributed to coumarins and phenolic compounds, the major compounds present in A. cearensis seed extracts. Multiple lines of research demonstrate these compounds reduce oxidative stress, inflammation and neuronal death induced by glutamate excitotoxicity, events central to most neuropathologies, including Alzheimer's disease (AD) and Parkinson's Disease (PD). This review focuses on the botanical aspects, folk medicine use, biological effects and pharmacological activities of A. cearensis compounds and their potential as novel non-toxic drugs for the treatment of neurodegenerative diseases.
\end{abstract}

Keywords: Amburana cearensis; pharmacological activities; central nervous system

\section{Introduction}

Native plants of the legume family (Fabaceae) from the Brazilian Caatinga, a semi-arid biome, represent a large number of plants with ethnopharmacological properties for the treatment of various diseases [1]. Among them, Amburana cearensis A.C. Smith is a naturally occurring tree that is widely distributed in Northeastern Brazil and widely exploited in folk medicine [2]. The stem bark and seeds of $A$. cearensis have well-known therapeutic properties in the form of teas, decocts and syrups in the treatments of various respiratory conditions and toothaches, in addition to the use of the stem bark in a bath to relieve rheumatic and spasmodic pain [3-5], whilst in Bolivia, the stem bark is crushed and applied directly on the head for headache [6]. 
A range of pharmacological properties of extracts and isolated compounds from the different parts of $A$. cearensis have been reported in the literature. These properties include the antibacterial effect of a stem bark chloroform extract [7], the in vitro anti-malarial effect of a stem bark dichloromethane extract and a variety of isolated compounds with anti-falciparum, leishmanicidal and bactericidal activities [2]. Many studies attribute the action of these compounds present mostly in the stem bark and seed extracts to their anti-inflammatory potential [8,9], which stimulated research into its effects in experimental models of central nervous system (CNS) diseases associated with neuroinflammation. Notably, in vitro studies have reported neuroprotective effects of coumarin-rich extracts of $A$. cearensis seeds, especially a dichloromethane extract, which has been shown to be cytoprotective in brain cell lines and primary cell cultures $[10,11]$ as well as a phenol glucoside from $A$. cearensis bark that protects against 6-hydroxydopamine toxicity [12]. These classes of compounds are known for their well characterized antioxidant actions and represent potential alternative therapies for neurodegenerative diseases. In this article, we present a review of the general aspects of $A$. cearensis botany and phytochemistry and the state of the art findings concerning $A$. cearensis pharmacological effects, including an overview of the latest findings on activities of $A$. cearensis products in CNS in vitro study models.

\section{Botany}

A. cearensis, popularly known in Brazil as "cumaru", "cerejeira" or "imburana/umburana de cheiro", is a tree that can grow to a height of up to $20 \mathrm{~m}$. It has a natural distribution in the Brazilian "Caatinga" desert biome and also in the pluvial forest [2]. Although it is considered native to Brazil, it is also frequently found in other South American countries, such as Peru and Argentina [13].

A. cearensis was established by A.C. Smith (1940) as a botanical synonymous for Torresea cearensis, named by Freire Allemão in 1864. This species is one out of two species from the small Amburana genus of the Fabaceae family. A. cearensis stalk is a trunk and its inflorescences are made of both yellow and white flowers. Its leaves usually measure 10-15 cm containing leaflets that are usually 2 $\mathrm{cm}$ large. Its pods are dark and contain one or two black elliptical flying seeds that contribute to its pollination. A main characteristic of $A$. cearensis is its brown-reddish stem bark that is easily peeled off $[5,14]$. The plant bark has a high economic value due to its use in woodwork, which contributed to A. cearensis being classified as an endangered species in the past. Nowadays, it is considered almost endangered by the Brazilian National Center of Flora Conservation (Centro Nacional de Conservação de Flora) [2,15]. One study suggests that it should be used in the early stages of a program to reforest degraded seasonal forests and in plantation trials [16].

A. cearensis stem bark is used in folk medicine due to its curative properties, together with the use of its seeds in teas, decocts and syrups for diseases such as asthma, bronchitis, cough and toothache, whilst a bath of stem bark is used for rheumatic and spasmodic pain relief $[5,13,17]$, particularly by indigenous natives [18].

\section{Toxicology}

Studies indicate that $A$. cearensis products are safe for consumption by both humans and other mammals. As described by Soares et al., 2007 [19], the chronic administration of an A. cearensis stem bark syrup $(50 \mathrm{mg} / \mathrm{mL})$ in twenty-four healthy male volunteers for four weeks demonstrated that this product is well tolerated according to biochemical, hematological, serological and clinical parameters (including electrocardiographic), and only two side effects were reported: dizziness (two volunteers) and nausea (one volunteer). The authors mentioned that many compounds were already isolated from A. cearensis trunk bark, including a coumarin that can alter prothrombin time and influence blood clot formation, and although it may induce acute side effects, such as hepatic necrosis, it has been shown to be safe overall, presenting only small fluctuations in renal and hepatic parameters. In another study by Leal et al., 2003 [20], the hydroalcoholic extract of $A$. cearensis stem bark at a dose of $500 \mathrm{mg} / \mathrm{kg}$ for up to 50 days did not show any teratogenicity and only altered alanine aminotransferase liver enzyme levels among all biochemical parameters measured; it also reduced the neutrophil counts in male rats 
and reduced creatinine concentration in female animals. A study by Costa-Lotufo et al., 2003 [21] showed that one hydroalcoholic extract of $A$. cearensis trunk bark, protocatechuic acid, can induce hemolysis in mouse erythrocytes, but the other extracts identified in the study did not (kaempferol, isokaempferide, amburoside A). Overall, these studies indicate that extracts of $A$. cearensis are non-toxic and well tolerated, presenting few side effects.

\section{Chemical Constituents}

Diverse pharmacological activities can be attributed to many secondary metabolites already characterized from several parts of the A. cearensis plant. From the trunk bark ethyl acetate extracts, Bravo B. et al., 1999 [22] identified two phenol glucosides in ethyl acetate extracts (amburoside A and amburoside B), in addition to coumarin (1-benzopyran-2-none) in the methylene chloride extract. Negri et al., 2004 [23] described predominantly phenolic compounds in the extracts from the stem bark, in particular coumarins (coumarin, dihydrocoumarin and scopoletin), phenylpropanoids (e.g., trans-methyl-3,4-dimethoxycinnamic acid), benzoic acids (e.g., methyl-3-methoxy-4-hydroxybenzoic acid), simple phenols (e.g., catechol and guaiacol) and the anthraquinone chrysophanol. Triterpenoids (e.g., lupeol and amyrins), steroids (e.g., $\gamma$-sitosterol), aliphatic esters (e.g., methyl palmitate) and other minor compounds were also detected in this study. Using the dry stem bark chloroform extract, Sá et al., 2014 [7] identified other different components: a benzenoid, 4-methoxy-3-methylphenol, together with bicyclic monoterpenes, such as $\alpha$-pinene and $\beta$-pinene and 4-hydroxy-3-methoxybenzoic acid. The ethanolic extract of stem bark obtained by Canuto and Silveira, 2010 [3] provided coumarin as the major compound, as well as two phenolic acids (vanillic acid and protocatechuic acid), amburoside A (a phenol glucoside), a mixture of glycolyzed phytosterols ( $\beta$-sitosterol and stigmasterol) and five flavonoids (afrormosin, isokaempferide, kaempferol, quercetin and $4^{\prime}$-methoxy-fisetin).

Proteins that represent protection mechanisms for the plants, especially the seeds, can be a source of molecules as tools for studying proteinase functions. Using A. cearensis seeds, authors have isolated TaTI (Torresea acreana trypsin inhibitor), a new member of the Bowman-Birk trypsin inhibitor family [24,25]. Furthermore, from A. cearensis seed hexane suspension, Rodrigues et al., 2008 [26] purified coumarin, using supercritical carbon dioxide and a semi-continuous flow apparatus. Using the same part of the plant, Pereira et al., 2017a [10] obtained an ethanolic extract (ETAC) and performed different partitions with hexane (EHAC), dichloromethane (EDAC) and ethyl acetate (EAAC); coumarin and its 3-methyl derivative, fatty acid esters (methyl octanoate, methyl hexadecanoate, methyl 13-trans-octadecanoate) and phytosterols like $\gamma$-sitosterol were identified in all partitions except in EAAC. Some of these metabolites are also present after germination, as described by Canuto and Silveira, 2010 [3]; using an ethanolic extract of both the ground parts and xylopodiums of young specimens, the authors purified nine compounds after dichloromethane partition, silica gel chromatography and other treatments, namely coumarin, isokaempferol, amburoside A, amburisode B, vanillic acid, p-hydroxybenzoic acid, aiapin, protocatechuic acid and $E-(o)$-glycosylated coumaric acid.

Coumarins appear to be the main secondary metabolites identified in A. cearensis. These compounds are natural benzopyrene derivatives that display important biological roles in vegetables and microorganisms. Coumarins are pharmacologically known as antioxidants and anti-inflammatory drugs [27-29] and are naturally present in various parts of the plant, controlling cell growth and energetic functions. Natural coumarins are synthesized through the shikimic acid pathway, and its first isolation dates to 1820 by Vogel. Ever since, a wide range of biological effects have been observed also from its synthetic derivatives, probably due to the simple structure of coumarins [30]. Antimicrobial, anti-inflammatory and antitumoral activities have been described for coumarins [21-23], but their more recognized biological activity is as an anticoagulant [24]. 


\section{Biological Activities}

Many biological effects of $A$. cearensis extracts and isolated compounds have been described (Table 1). Sá et al., 2014 [7] demonstrated the bacteriostatic activity of the stem bark chloroform extract on Pseudomonas aeruginosa and Bacillus cereus strains, with a minimum inhibitory concentration (MIC) of $6900 \mu \mathrm{g} / \mathrm{mL}$. In addition, this work describes the broad-spectrum bactericidal effect of the synthetic 2-methoxy-4-methylphenol (MIC 215 to $431 \mu \mathrm{g} / \mathrm{mL}$ ), a purchased compound analogue to 4-methoxy-3-methylpoliphenol, contained in the extract.

Table 1. Isolated compounds from different extracts and parts of $A$. cearensis and related biological activities.

\begin{tabular}{|c|c|c|c|c|}
\hline Author (Year) & Plant Part & Extract & Isolated Compounds & Activity \\
\hline Leal et al., 1997 & Bark & $\begin{array}{l}\text { Hydroalcoholic } \\
\text { extract }\end{array}$ & $\begin{array}{l}\text { Coumarin; isokaempferol, } \\
\text { flavonoids (fraction). }\end{array}$ & $\begin{array}{l}\text { Hydroalcoholic extract and } \\
\text { coumarin: anti-nociceptive; } \\
\text { anti-inflammatory }\end{array}$ \\
\hline Bravo B. et al., 1999 & Bark & $\begin{array}{l}\text { Dichloromethane } \\
\text { extract }\end{array}$ & $\begin{array}{l}\text { Coumarin, Amburoside A, } \\
\text { Amburoside B. }\end{array}$ & $\begin{array}{l}\text { Extract: anti-plasmodium } \\
\text { Coumarin: leishmanicidal, } \\
\text { bactericidal and antimalarial } \\
\text { Amburoside A: antimalarial }\end{array}$ \\
\hline Leal et al., 2000 & Bark & $\begin{array}{l}\text { Hydroalcoholic } \\
\text { extract }\end{array}$ & - & $\begin{array}{c}\text { Antinociceptive, } \\
\text { anti-inflammatory and } \\
\text { bronchodilator }\end{array}$ \\
\hline Costa-Lotufo, 2003 & Bark & Methanolic extract & $\begin{array}{c}\text { kaempferol, isokaempferide, } \\
\text { amburoside A and } \\
\text { protocatechuic acid }\end{array}$ & $\begin{array}{l}\text { Isolated compounds: } \\
\text { antiproliferative and } \\
\text { antioxidant }\end{array}$ \\
\hline Leal et al., 2003a & Bark & $\begin{array}{l}\text { Hydroalcoholic } \\
\text { extract }\end{array}$ & $\begin{array}{c}\text { Coumarin; } \\
\text { 3,4,5-trihydroxi-benzoic acid; } \\
\text { isokaempferol; fisetin and } \\
\text { a biflavonoid }\end{array}$ & $\begin{array}{l}\text { Extract, coumarin and } \\
\text { flavonoid fraction: } \\
\text { anti-inflammatory; } \\
\text { (bronchodilator). }\end{array}$ \\
\hline Marinho et al., 2004 & Bark & $\begin{array}{l}\text { Hydroalcoholic } \\
\text { extract }\end{array}$ & Coumarin & $\begin{array}{l}\text { Immunomodulation of } \\
\text { specific antibodies; vascular } \\
\text { permeability reduction. }\end{array}$ \\
\hline Leal et al., 2005 & Bark & Ethanolic extract & Amburoside A & $\begin{array}{l}\text { Amburoside A: } \\
\text { neuroprotective }\end{array}$ \\
\hline Leal et al., 2008 & Bark & Ethanolic extract & Amburoside A & $\begin{array}{l}\text { Hepatoprotective and } \\
\text { anti-inflammatory }\end{array}$ \\
\hline Farias et al., 2010 & Seeds & Aqueous extract & - & $\begin{array}{c}\text { Toxicity against Aedes aegypti } \\
\text { larvae }\end{array}$ \\
\hline Lima et al., 2013 & Seeds & Aqueous extract & - & Anti-edematous \\
\hline Lopes et al., 2013 & Bark & Ethanolic extract & Afrormosin & $\begin{array}{l}\text { Afrormosin: inhibition of } \\
\text { neutrophil responses }\end{array}$ \\
\hline Sá et al., 2014 & Bark & Chloroform extract & - & Extract: bacteriostatic \\
\hline Barberino et al., 2015 & Leaves & Ethanolic extract & - & $\begin{array}{l}\text { Extract: improves in } \\
\text { vitro development of ovine } \\
\text { secondary follicles }\end{array}$ \\
\hline Gouveia et al., 2016 & Leaves & Ethanolic extract & - & $\begin{array}{c}\text { Improves in vitro } \\
\text { development of } \\
\text { caprine preantral follicles }\end{array}$ \\
\hline Pereira et al., 2017a & Seeds & $\begin{array}{l}\text { Ethanolic extract } \\
\text { and fractions }\end{array}$ & - & $\begin{array}{l}\text { Ethanolic extracts and } \\
\text { fractions: neuroprotective } \\
\text { (glutamate-induced } \\
\text { excitotoxicity) to cell lines }\end{array}$ \\
\hline Pereira et al., 2017b & Seeds & $\begin{array}{l}\text { Ethanolic extract } \\
\text { and fractions }\end{array}$ & - & $\begin{array}{l}\text { Ethanolic extracts and } \\
\text { fractions: neuroprotective } \\
\text { (glutamate-induced } \\
\text { excitotoxicity) to } \\
\text { primary culture }\end{array}$ \\
\hline Oliveira et al., 2020 & Seeds & $\begin{array}{l}\text { Protein extract } \\
\text { and fractions }\end{array}$ & - & $\begin{array}{l}\text { Synergistic antibacterial effect } \\
\text { against } S \text {. aureus and E. coli; } \\
\text { trypsin activity inhibitor. }\end{array}$ \\
\hline
\end{tabular}


Recently, Oliveira et al., 2020 [31] have shown a potential synergistic antibacterial effect of total protein extract of $A$. cearensis seeds and three fractions obtained from precipitation with different ammonium sulfate concentrations against Staphylococcus aureus and Escherichia coli strains, together with known antibacterial drugs (norfloxacin, penicillin and gentamicin). The crude extract, together with the three antibiotics, inhibited S. aureus and E. coli growth. In comparison, the three fractions presented non-homogeneous results. Additionally, the three ammonium sulfate fractions were able to inhibit the activity of the serine protease trypsin, which, in plants, has a key role in regulating proteolytic effects and modulating apoptosis, and is a representative of the plant's defense system.

In another study, Bravo B. et al., 1999 [22] reported the in vivo anti-malarial effect of dichloromethane stem bark extract against a Plasmodium falciparum strain sensitive to chloroquine in mice. The extract inhibited $50 \%$ of the parasite activity at a concentration (IC50) of $9 \mu \mathrm{g} / \mathrm{mL}$. Isolated compounds from the extract, coumarin (1-benzopyran-2-ona, Figure 1A) and amburoside A (Figure 1B), at a dose of $50 \mathrm{mg} / \mathrm{kg} / \mathrm{day}$, administered for 4 days, also reduced the parasitemia by 25 and $24 \%$ in mice, respectively. Moreover, in vitro, coumarin itself, at a concentration of $50 \mu \mathrm{g} / \mathrm{mL}$, could reduce the viability of Leishmania amazonensis, L. braziliensis and L. donovani at a concentration of $50 \mu \mathrm{g} / \mathrm{mL}$.<smiles>[R]c1cc(C(=O)OCc2ccc(O[C@@H]3O[C@H](CO)[C@@H](O)[C@H](O)[C@H]3O)cc2)ccc1O</smiles><smiles>O=c1c(O)c(-c2ccc(O)c(O)c2)oc2cc(O)ccc12</smiles><smiles>O=c1c(OP)c(-c2ccc(O)cc2)oc2cc(O)cc(O)c12</smiles><smiles>COc1cc2oc(-c3ccc(O)cc3)cc(=O)c2cc1O</smiles>

Figure 1. Representative chemical structures of A. cearensis bioactive compounds. (A) Coumarin (1,2-benzopyrone); (B) phenol glucosides amburoside A and amburoside B; (C) fisetin; (D) flavonoids kaempferol and isokaempferide; (E) flavonoid afrormosin.

Farias et al., 2010 [32] described A. cearensis aqueous extract as being 100\% toxic for Aedes aegypt mosquito larvae, a species that is a vector for a variety of viruses with significant epidemiology in Brazil. Toxicity was observed within $3 \mathrm{~h}$ from a concentration of $24.75 \pm 1.31 \mathrm{mg} / \mathrm{mL}$ of soluble solids, obtaining a LC50 $=8.10 \pm 0.27 \mathrm{mg} / \mathrm{mL}$. Using phytochemical rapid analysis of the extracts, the authors detected the presence of tannins, phenols and flavones. This study also mentions the extracts have trypsin inhibition activity, with $12.23 \pm 0.29 \mathrm{~g}$ of trypsin being inhibited per $\mathrm{kg}$ of extract. Together, these findings suggest that $A$. cearensis extract contains molecules that are involved in plant defense and can act as larvicidal via inhibition of proteases. Interestingly, the extract did not present acute toxicity for mice $(30 \mathrm{~mL} / \mathrm{Kg})$.

Two studies mention the potential of $A$. cearensis leaf ethanolic extract in modulating the ovarian follicle cycle. Barberino et al. (2015) [33] tested the extract $(0.1-0.4 \mathrm{mg} / \mathrm{mL})$ in cultured ovine ovaries 
and showed that it maintains ovary viability in the absence of supplements for up to 18 days after culture (particularly $0.1 \mathrm{mg} / \mathrm{mL}$ ). Gouveia et al., 2016 [34] tested the leaf extract in caprine ovaries and found the extract improves follicle growth and survival in supplemented media (particularly $0.2 \mathrm{mg} / \mathrm{mL})$.

A. cearensis compounds have also been tested for anticancer activities. In a study by Costa-Lotufo, 2003 [21], kaempferol, isokaempferide, amburoside A and protocatechuic acid, isolated from $A$. cearensis trunk bark methanolic extract, have shown cytotoxic effects against cancer cell lines B-16 (murine skin cancer), HCT-8 (human colon cancer), MCF-7 (human breast cancer) and CEM and HL-60 (leukemia), using the MTT (3-(4,5-dimethyl-2-thiazolyl)-2,5-diphenyl-2H-tetrazolium bromide) viability assay. The authors have also tested the antiproliferative activity in a sea urchin model, and it was demonstrated that isokaempferide and kaempferol inhibited sea urchin egg development, as well as induced cytotoxicity in tumor cell lines, but in this assay isokaempferide was more potent than kaempferol.

The assortment of biological activities of $A$. cearensis may justify its popular ethnopharmacological use as an anti-inflammatory and analgesic agent. Leal et al., 2008 [35] have shown that both 25 and $50 \mathrm{mg} / \mathrm{kg}$ of amburoside $\mathrm{A}$ isolated from $A$. cearensis trunk bark reduced liver necrosis and the inflammatory infiltrate in the liver parenchyma in a carbon tetrachloride model of induced liver injury. Furthermore, this compound normalized catalase activity and decreased the induced lipid peroxidation.

Leal et al., 1997 [8] demonstrated an antiedematogenic effect of $A$. cearensis stem bark hydroalcoholic extract (HAE), its flavonoid fraction and coumarins, in a carrageenan and dextran-induced rad paw edema model; coumarins (10 and $20 \mathrm{mg} / \mathrm{kg}$ ) and HAE (100 and $200 \mathrm{mg} / \mathrm{kg}$ ) induced a dose-dependent reduction of paw edema and inflammatory exudates, whilst HAE also reduced the number of abdominal contractions induced by acetic acid by up to 49\%. In the same study, HAE (100, $200 \mathrm{and} 400 \mathrm{mg} / \mathrm{kg}$ ) and coumarins ( 5 and $10 \mathrm{mg} / \mathrm{kg}$ ) decreased nociception in male Swiss mice by increasing the latency time in a hot-plate test in a dose-dependent manner. In another study by Leal et al. (2000) [36], with a view to investigating the pharmacological use for respiratory tract diseases, the antinociceptive and anti-inflammatory activities of hydroalcoholic extracts from $A$. cearensis stem bark extract were reproduced, and the extract also showed bronchodilator activity in an acetic acid-induced writhing model in mice. A phytochemical study showed that the extract tested positive for the presence of coumarin, flavonoids, saponins and tannins.

Two other works corroborate these effects of A. cearensis compounds. Lima et al., 2013 [14] have shown an antiedematogenic effect of the stem bark aqueous extract (10\% and 20\%) in a carrageenan-induced paw edema model. In the same study, this extract presented mutagenic effects, which might amplify the necessity of toxicological assays on the products of this species to make its use safe. Moreover, Leal et al., 2003 [37] isolated coumarin (5 mg/kg) and a flavonoid fraction (FF) $(20 \mathrm{mg} / \mathrm{kg})$ from HAE $(150 \mathrm{mg} / \mathrm{kg})$, and oral administration of both compounds in Wistar rats reduced cutaneous vascular permeability induced by serotonin; the HAE also reduced vascular permeability induced by histamine. The authors also demonstrated that HAE (200 and $400 \mathrm{mg} / \mathrm{kg}$ ), FF (10, 20 and $40 \mathrm{mg} / \mathrm{kg}$ ) and coumarin (20 and $40 \mathrm{mg} / \mathrm{kg}$ ) inhibited neutrophil and leukocyte migration into the peritoneal cavity induced by carrageenan and $N$-formylmethionine-leucyl-phenylalanine. The HAE and FF compounds were also able to induce trachea muscle relaxation in Guinea pig, which might suggest both anti-inflammatory and bronchodilator effects.

In this light, afrormosin, a flavonoid isolated from A. cearensis trunk bark, reduced the myeloperoxidase release by human neutrophils and other neutrophil responses after the cells were stimulated by phorbol 12-myristate-13-acetate (PMA). In this model, analysis of the cell suspension demonstrated that afrormosin reduced neutrophil degranulation (IC50 $=0.37 \mu \mathrm{M})$ and TNF- $\alpha$ levels up to $44 \%$ and showed an antioxidant effect from at least $83.8 \mu \mathrm{M}$ concentration [38].

Another study by Marinho et al., 2004 [9] showed paw edema induced by ovalbumin sensibilization was reduced using trunk bark HAE administrated orally $(400 \mathrm{mg} / \mathrm{kg})$ or intraperitoneally $(100 \mathrm{mg} / \mathrm{kg})$, as well as extracted coumarin (10 and $20 \mathrm{mg} / \mathrm{kg}$ ) administrated intraperitoneally. In this work, both 
HAE and coumarin specifically reduced anti-ovalbumin immunoglobulin levels. Moreover, HAE (100 and $200 \mathrm{mg} / \mathrm{kg}$ intraperitoneal) also inhibited acetic acid-induced vascular permeability.

\section{Neuroprotective Activities of $A$. cearensis Compounds}

Neurodegenerative diseases (ND) result in chronic and progressive degeneration of neurons, which leads to cognitive, neuropsychiatric, behavioral and/or motor symptoms. These diseases are often related to ageing and the inability of both neurons and glial cells to proliferate and compensate for insults and cell death. Currently, ND represent a major public health priority around the globe as life expectancy increases, mainly in European and North American countries. Alzheimer's disease (AD) is the most common ND, with the World Health Organization (WHO) estimating in 2012 that 35.6 million people worldwide were living with dementia (with $\mathrm{AD}$ accounting for $60-70 \%$ ) and that this number would double by 2030 and triple in 2050, bringing more social and economic impacts than cancer $[39,40]$. The second most common ND is Parkinson's disease (PD), with 6.1 million people worldwide having this disease in 2016 [41,42]. In addition to ND, stroke is another important CNS pathology that stands out for alarming statistical data. Data reported in 2011 show that approximately 800,000 primary (first-time) or secondary (recurrent) strokes occur each year in the US; of these strokes, approximately $87 \%$ are ischemic infarctions, $10 \%$ are primary hemorrhages and $3 \%$ are subarachnoid hemorrhages [43].

Despite extensive research, particularly over the last 30 years, the specific causes of neuron loss in ND remain unclear and are likely to be multifactorial. There are multiple hypotheses for the causes of neuron loss in different neuropathologies, many of which are complementary. For example, it is well known that misfolded proteins and peptide aggregates can lead to neural toxicity, such as $\alpha$-synuclein in PD and $\beta$-amyloid in AD [44]. In PD, it is common knowledge that dopaminergic neurons degenerate, especially in the substantia nigra of the striatum. These cells contain neuromelanin, a natural endogenous product formed by the oxidation of dopamine to aminochrome, a more stable molecule [45-47]. Studies have demonstrated that aminochrome induces the formation of neurotoxic oligomers that can stabilize toxic alpha-synuclein protofibrils $[48,49]$. Neurotoxicity is also related to the presence of $\alpha$-synuclein aggregates in Lewy bodies in the neuron cytoplasm, which contributes to mitochondrial damage and oxidative stress [50-52]. In AD, the accumulation of $\beta$-amyloid peptides in the extracellular space and neurofibrillary tangles also leads to toxicity to neurons, mainly cholinergic neurons, of the frontal cortex, parietal lobe, frontal lobe, limbic structures and the cortex-hippocampal connections. In addition, there may be an accumulation of intracellular misfolded tau proteins [53-55].

Oxidative stress is another common factor in ND, for example accelerating dopamine degradation and $\alpha$-synuclein toxicity in PD $[48,56]$, and might be considered as the main hypothesis for neuronal death, because it impairs the cellular antioxidant defense ability $[57,58]$. Reactive oxygen species (ROS) followed by a decrease in the potential for cellular antioxidant defense is one of the main hypotheses of mechanisms for triggering apoptosis of nigrostriatal neurons in PD and patients with PD having higher blood concentrations of oxidative markers [59,60]. Oxidative stress is also considered the earliest event in the appearance of $\mathrm{AD}[52,58,61]$. In addition, oxidative stress can impair the reduced and oxidized glutathione antioxidant system (GSH/GSSG) [62], enhance basal lipid peroxidation and increase the activity of mitochondrial superoxide dismutase [63]. Mitochondrial complex IV is also affected in AD and, together with astrocyte and microglia activation and neuronal death, can lead to the production of pro-inflammatory factors that can start or persist degeneration [64,65].

Glutamate-mediated excitotoxicity is a further factor in the etiology of neuronal death in ND and stroke [66-68]. Glutamate is the most abundant neurotransmitter in the CNS and under pathological conditions can accumulate extracellularly, which leads to the process known as "glutamatergic excitotoxicity". Besides being involved in acute brain ischemia, this process leads to metabolic changes that are known as a final and convergent pathway in neuronal death among many ND [69,70]. Excessive levels of glutamate in the CNS, resulting from hypoxia, physical trauma and/or a failure in the reuptake of this neurotransmitter by astrocytes, can trigger signaling cascades that culminate in excessive $\mathrm{Ca}^{2+}$ 
entry into cells and the activation of cell death cascades, deregulation of mitochondrial membrane potentials and oxidative stress [71-73]. These events are related to neuronal death in both experimental AD and PD $[53,74]$.

Neuroinflammation also plays a critical role in neurodegeneration. Inflammation is a physiologically important mechanism for containing insults. However, when the inflammatory response is exacerbated in the CNS, it can be irreversible for neural cells. Neurodegenerative and neurological diseases can often present reactive gliosis as a pathological finding, where glial cells, mostly astrocytes and microglia, respond to insults by secreting pro-inflammatory factors and changing their phenotype in a way that restricts a lesion [75-78]. The secretion of molecules, such as interleukins, chemokines and reactive species of oxygen and nitrogen by microglia and astrocytes, can lead to their chronic activation and prompt them towards a toxic phenotype, which in turn promotes more neuronal death. Microglia, astrocytes and neurons are able to release these molecules, which might be involved in the initiation and progression of neurodegeneration $[79,80]$. In post mortem tissue, activated microglia were found in the substantia nigra in PD, and surrounding senile plaques and tau protein tangles in AD [81]. Microglia are the intrinsic immune cells of the CNS and exhibit multiple states of activation in response to pathology. Although microglial activation states display a high degree of heterogeneity, two distinct polarized microglial phenotypes have been described in the literature, based on expression of specific proteins and cytokines/chemokines, termed pro-inflammatory M1 microglia and regulatory M2 microglia. The more pro-inflammatory microglial phenotype is characterized by production of cytokines such as IL-1 $\beta$ and TNF, which is essential for controlling tissue damage and cleaning cell debris. The switch to a more regulatory M2 phenotype can be characterized by the secretion of factors such as IL-4 and IL-10 that promote brain repair [82,83]. For demyelinating diseases, such as multiple sclerosis (MS), there is an infiltration of Th1 lymphocytes from the immune system into the nervous system that recognize myelin and start a cytokine-mediated reaction that stimulates microglia and infiltrated macrophages to produce IL-12 and ROS, culminating in axonal and, consequently, neuronal death $[80,84,85]$. There is now an abundance of evidence from microglial transcriptomic and proteomic profiles that characterizing microglia as being exclusively in an M1 or M2 state is over simplistic and this classification should not be used going forward. However, the M1/M2 terminology remains in use as an indicator of microglial function, and it is evident that modulating the inflammatory functions of microglia is an important therapeutic strategy in ND.

Frequently, anti-inflammatory drugs are described to have neuroprotective effects [86-89], as demonstrated in models of ND. Hence, antioxidant substances, such as coumarins, are of interest in the research on therapeutic and preventive treatments for ND. In addition, other phenolic and benzopyran derivative compounds, such as flavonoids, are well known as anti-inflammatory drugs that can modulate the expression of cytokines and inflammatory transcription factors, such as NF- $\mathrm{kB}$, nitric oxide synthase (iNOS) and, consequently, nitric oxide expression [27,30,90]. Flavonoids are also neuroprotective both in vitro and in vivo and are capable of controlling cytokine, chemokine and ROS expression [10,11,91-93].

There is positive evidence for the pharmacological application of $A$. cearensis compounds in ND models. The $A$. cearensis stem bark extract at a concentration of $2.3 \mathrm{mg} / \mathrm{mL}$ has been shown to effectively inhibit acetylcholinesterase activity in microplate and thin-layer chromatography assays [94]. Acetylcholinesterase inhibitors are the most commonly used drugs for treating AD and other types of dementia [95]. Although they cannot stop the progression of the disease, acetylcholinesterase inhibitors act by increasing brain levels of acetylcholine, which are decreased in AD due to degeneration of cholinergic neurons, especially in the forebrain [96].

Leal et al., 2005 [12] examined the effects of amburoside A from A. cearensis trunk bark in an in vitro model of PD, using 6-hydroxydopamine (6-OHDA) in mesencephalic cells from Wistar rat embryos. 6-OHDA is used as an in vitro and in vivo model for PD because it is an endogenous compound formed by dopamine oxidation that induces dopaminergic neuronal degradation and is involved in the pathogenesis of PD. 6-OHD has been shown to induce many of the molecular findings 
in PD in vitro and in vivo, such as oxidative stress, mitochondrial damage, neuroinflammation and cell death via apoptosis [97-99]. Using the MTT toxicity assay, Leal et al., 2005 [12] showed that amburoside $\mathrm{A}$ was not toxic in any of the concentrations tested and that pre-treatment at concentrations starting from $0.5 \mu \mathrm{g} / \mathrm{mL}$ protected the cell culture from reduced viability induced by 6-OHDA toxicity. Amburoside A at concentrations of $0.1-10 \mu \mathrm{g} / \mathrm{mL}$ also decreased cell culture nitric oxide production when compared to 6-OHDA. Furthermore, the increase in the levels of thiobarbituric acid reactive substances (TBARS) induced by 6-OHDA, an indication of lipid peroxidation [100], was inhibited by pre-treatment with amburoside $\mathrm{A}$. The findings together show that amburoside $\mathrm{A}$ is a neuroprotective agent for cell culture of mesencephalon/midbrain, an important region for PD [88,101], and, as for other phenolic compounds [92], can act as an anti-inflammatory and antioxidant compound capable of reducing reactive nitrogen species [102].

A. cearensis compounds have been shown to have neuroprotective effects in ND-related models of glutamatergic excitotoxicity. In a work by Pereira et al. (2017a) [10], extracts from A. cearensis seeds protected a neuronal PC-12 cell line from neurotoxicity when exposed to high concentrations of glutamate $(1 \mathrm{mM})$; the authors tested four different partitions: an ethanolic extract (ETAC) and its partitions with hexane (EHAC), dichloromethane (EDAC) and ethyl acetate (EAAC). None of these extracts were neurotoxic at a range of concentrations tested $(0.1$ to $2000 \mu \mathrm{g} / \mathrm{mL})$, except EHAC, which reduced cell viability at the highest concentration tested $(1000 \mu \mathrm{g} / \mathrm{mL})$ after $72 \mathrm{~h}$ of treatment. The EDAC was characterized by Pereira et al., 2017a [10] as having the richest extract in coumarins and fatty acids esters, such as methyl hexadecanoate, ethyl hexadecanoate and methyl 13-octadecanoate. In another study by Pereira et al., 2017b [11], the effects of EHAC, EDAC and EAAC were tested in a more complex in vitro model, in cerebellum primary cultures, which contain neurons, astrocytes, microglia and progenitor cells. A. cerarensis extracts showed no toxicity to cerebellar cells in concentrations ranging from 0.1 to $100 \mu \mathrm{g} / \mathrm{mL}$ for up to $72 \mathrm{~h}$ treatments and protected the cells from neuronal degeneration induced by high levels of glutamate. The EDAC fraction also prevented morphological changes induced by glutamate in neurons and astrocytes; the latter displayed typical astrogliosis induced by glutamate, with an increase of glial fibrillary astrocyte protein (GFAP) and glutamine synthetase (GS) expression, which suggested that $A$. cearensis seed extracts may act by controlling astrocytic metabolism and neuroprotective properties.

As described above, most of the molecules present in bioactive $A$. cearensis extracts and fractions are phenolic compounds, such as coumarin, phenol glucosides and flavonoids (Figure 1). These compounds are versatile molecules that have been tested in CNS models and are known for their neuroprotective effects [92]. In vitro and in vivo studies show that phenolic compounds, including fisetin and coumarins, present in $A$. cearensis can act as antioxidants and reduce oxidative stress and mitochondrial damage [103-106], act as an anti-inflammatory by reducing the levels of pro-inflammatory cytokines that can initiate and persist chronic inflammation and increasing the levels of regulatory cytokines [107-109], reduce misfolded protein cytotoxicity [110,111], act as neurogenic drugs [93,112] and modulate glutamate cytotoxicity $[93,113,114]$. To sum up, these compounds from $A$. cearensis can act in a multitargeted way to reduce neurodegeneration and improve neural cell function and viability.

\section{Conclusions}

Amburana cearensis A.C. Smith is an endemic tree from Northeastern Brazil that is used in folk medicine. The folk use of Amburana cearensis has been justified by scientific research describing the pharmacological properties of the compounds present in extracts from several parts of this plant. Importantly, there is growing evidence that compounds extracted from the seeds of Amburana cearensis are a source of novel neuroprotective compounds, including coumarin, phenol glucosides, such as amburoside A, and flavonoids, and can target multiple neurodegenerative diseases, particularly because of their ability to reduce oxidative stress, inflammation and neuronal death induced by glutamate excitotoxicity. 
Author Contributions: J.H.C.eS. contibuted in data curation and writing, original draft, performed revision, interpreted the data and was the major contributor in writing the manuscript. R.S.F., E.P.P., S.B.-d.-S., and M.M.A.d.A., contibuted in data curation and writing original draft of the manuscript. C.C.d.S. interpreted the data and contributed in writing the manuscript. A.M.B. revised the manuscript critically for intellectual content and writing. E.C. revised the manuscript intellectual content. R.C. revised the manuscript critically for intellectual content, supervised wrtting, edited and reviewed the manuscript. V.D.A.d.S. and S.L.C. designed the manuscript, supervised writing, edited and reviewed the manuscript critically for intellectual content. All authors have read and agreed to the published version of the manuscript.

Funding: This research was in part supported by Bahia State Research Foundation (FAPESB, Call 011/2013-Support for Network Research Projects, Project RED0016/2013) and the National Council for Scientific and Technological Development (CNPq, Call MCTI//Universal 14/2014, Process 443723/2014-1, and Research Fellowship by Research Productivity to SLC, Process 307539/2018-0). AMB received support from the Multiple Sclerosis Society (Award Reference: 40) and the Biological Sciences Research Council (grant number: BB/M029379/1).

Acknowledgments: The authors give thanks to Coordination for the Improvement of Higher Education Personnel for MPhil fellowships to JHCS (CAPES, Process $N^{\circ} 88881.117666 / 2016-01$ and Processes number 88887.503664/2020-00) in the Postgraduate Program in Immunology of the Federal University of Bahia.

Conflicts of Interest: The authors declare no conflict of interest.

\section{References}

1. Marinho, M.G.V.; Silva, C.C.; Andrade, L.H.C. Levantamento etnobotânico de plantas medicinais em área de caatinga no município de São José de Espinharas, Paraíba, Brasil. Rev. Bras. Plantas Med. 2011, 13, 170-180. [CrossRef]

2. Almeida, J.R.G.S.; Guimarães, A.G.; Quintans, J.D.S.S.; Santos, M.R.V.; Lima, J.T.; Nunes, X.P.; Quintans-Júnior, L.J. Amburana cearensis-uma revisão química e farmacológica. Sci. Plena 2010, 6, 1-8.

3. Canuto, K.M.; Silveira, E.R.; Bezerra, A.M.E. Estudo fitoquímico de espécimens cultivados de cumaru (Amburana cearensis A.C. Smith). Quim. Nova 2010, 33, 662-666. [CrossRef]

4. Melo, C.d.A.; Souza, P.O.; Damasceno, E. Atividade farmacológica da planta Amburana cearensis (imburana) frente a estudo etnofarmacológico em Monte Azul-Mg. Rev. Bras. Pesqui. em Ciências da Saúde 2014, 1, 31-34.

5. Loureiro, M.B. Aspectos morfoanatômicos e fisiológicos de sementes e plântulas de Amburana cearensis (Fr. All.) A.C. Smith (Leguminosae-Papilionoideae). Rev. Árvore 2013, 37, 679-689. [CrossRef]

6. Zambrana, N.Y.P.; Zambrana, N.Y.P.; Bussmann, R.W. La Etnobotánica de los Chácobo en el siglo XXI. Ethnobot. Res. Appl. 2018, 16,1-149. [CrossRef]

7. Sá, M.B.; Ralph, M.T.; Nascimento, D.C.O.; Ramos, C.S.; Barbosa, I.M.S.; Sá, F.B.; Lima-Filho, J.V. Phytochemistry and preliminary assessment of the antibacterial activity of chloroform extract of Amburana cearensis (Allemão) A.C. Sm. against klebsiella pneumoniae carbapenemase-producing strains. Evid.-Based Complement. Altern. Med. 2014, 2014, 7. [CrossRef]

8. Leal, L.K.A.M.; Matos, M.E.; Matos, F.J.A.; Ribeiro, R.A.; Ferreira, F.V.; Viana, G.S.B. Antinociceptive and antiedematogenic effects of the hydroalcoholic extract and coumarin from Torresea cearensis Fr. All. Phytomedicine 1997, 4, 221-227. [CrossRef]

9. Marinho, M.D.G.V.; De Brito, A.G.; Carvalho, K.D.A.; Bezerra-Santos, C.R.; Andrade, L.D.H.C.; Barbosa-Filho, J.M.; Piuvezam, M.R. Amburana cearensis e cumarina imunomodulam os níveis de anticorpos antígeno-especffico em camundongos BALB/c sensibilizados com ovalbumina. Acta Farm. Bonaer. 2004, 23, 47-52.

10. Pereira, E.P.L.; Braga-De-Souza, S.; Santos, C.C.; Santos, L.O.; Cerqueira, M.D.; Ribeiro, P.R.; Fernandez, L.G.; Silva, V.D.A.; Costa, S.L. Amburana cearensis seed extracts protect PC-12 cells against toxicity induced by glutamate. Brazilian, J. Pharmacogn. 2017, 27, 199-205. [CrossRef]

11. Lima Pereira, É.P.; Santos Souza, C.; Amparo, J.; Short Ferreira, R.; Nuñez-Figueredo, Y.; Gonzaga Fernandez, L.; Ribeiro, P.R.; Braga-de-Souza, S.; Amaral da Silva, V.D.; Lima Costa, S. Amburana cearensis seed extract protects brain mitochondria from oxidative stress and cerebellar cells from excitotoxicity induced by glutamate. J. Ethnopharmacol. 2017, 209, 157-166. [CrossRef] [PubMed]

12. Leal, L.K.A.M.; Nobre, H.V.; Cunha, G.M.A.; Moraes, M.O.; Pessoa, C.; Oliveira, R.A.; Silveira, E.R.; Canuto, K.M.; Viana, G.S.B. Amburoside A, a glucoside from Amburana cearensis, protects mesencephalic cells against 6-hydroxydopamine-induced neurotoxicity. Neurosci. Lett. 2005, 388, 86-90. [CrossRef] [PubMed] 
13. Canuto, K.M.; Silveira, E.R. Constituíntes químicos da casca do caule de Amburana cearensis A.C. SMITH. Quim. Nova 2006, 29, 1241-1243. [CrossRef]

14. Lima, L.R.; Cavalcante, R.R.L.; Martins, M.C.C.; Parente, D.M.; Cavalcante, A.A.M.C. Avaliação da atividade antiedematogênica, antimicrobiana e mutagênica das sementes de Amburana cearensis (A.C. Smith) (Imburana-de-cheiro). Rev. Bras. Plantas Med. 2013, 15, 415-422. [CrossRef]

15. Cunha, M.d.C.L.; Ferreira, R.A. Aspectos morfológicos da semente e do desenvolvimento da planta jovem de Amburana cearensis (Arr. Cam.) A.C. Smith-Cumaru-Leguminosae Papilionoideae. Rev. Bras. Sementes 2003, 25, 89-96. [CrossRef]

16. Ramos, K.M.O.; Felfili, J.M.; Fagg, C.W.; Sousa-Silva, J.C.; Franco, A.C. Desenvolvimento inicial e repartição de biomassa de Amburana cearensis (Allemao) A.C. Smith, em diferentes condições de sombreamento. Acta Bot. Brasilica 2004, 18, 351-358. [CrossRef]

17. De Carvalho Nilo Bitu, V.; De Carvalho Nilo Bitu, V.; Matias, E.F.F.; De Lima, W.P.; Da Costa Portelo, A.; Coutinho, H.D.M.; De Menezes, I.R.A. Ethnopharmacological study of plants sold for therapeutic purposes in public markets in Northeast Brazil. J. Ethnopharmacol. 2015, 172, 265-272. [CrossRef]

18. Maia de Morais, S.; Pereira Dantas, J.D.; Raquel Araújo da Silva, A.; Farias Magalhães, E. Plantas medicinais usadas pelos índios Tapebas do Ceará. Rev. Bras. Farmacogn. Brazilian, J. Pharmacogn. 2005, 15, 169-177. [CrossRef]

19. Soares, A.K.A.; Sampaio, I.L.; Santana, G.S.M.; Bezerra, F.A.F.; Moraes, M.O.; Moraes, M.E.A. Clinical toxicology study of a herbal medicine formulation of Torresea cearensis in healthy volunteers. Rev. Bras. Plantas Med. 2007, 9, 55-60.

20. Leal, L.K.A.M.; Oliveira, F.G.; Fontenele, J.B.; Ferreira, M.A.D.; Viana, G.S.B. Toxicological study of the hydroalcoholic extract from Amburana cearensis in rats. Pharm. Biol. 2003, 41, 308-314. [CrossRef]

21. Costa-Lotufo, L.V.; Jimenez, P.C.; Wilke, D.V.; Leal, L.K.A.M.; Cunha, G.M.A.; Silveira, E.R.; Canuto, K.M.; Viana, G.S.B.; Moraes, M.E.A.; De Moraes, M.O.; et al. Antiproliferative Effects of Several Compounds Isolated from Amburana cearensis A.C. Smith. Zeitschrift fur Naturforsch. C 2003, 58, 675-680. [CrossRef] [PubMed]

22. Bravo B., J.A.; Sauvain, M.; Gimenez, A.; Muñoz, V.; Callapa, J.; Le Men-Olivier, L.; Massiot, G.; Lavaud, C. Bioactive phenolic glycosides from Amburana cearensis. Phytochemistry 1999, 50, 71-74.

23. Negri, G.; Oliveira, A.F.M.; Salatino, M.L.F.; Salatino, A. Chemistry of the stem bark of Amburana cearensis (Allemão) (A.C.SM.). Rev. Bras. Plantas Med. 2004, 6, 1-4.

24. Tanaka, A.S.; Sampaio, M.U.; Mentele, R.; Auerswald, E.A.; Sampaio, C.A.M. Sequence of a new bowman-birk inhibitor from Torresea acreana seeds and comparison with Torresea cearensis trypsin inhibitor (TcTI2). J. Protein Chem. 1996, 15, 553-560. [CrossRef] [PubMed]

25. Tanaka, A.S.; Sampaio, M.U.; Oliva, M.L.V.; Sampaio, C.A.M.; Marangoni, S.; de Oliveira, B.; Novelle, J.C.; Fink, E. Purification and Primary Structure Determination of a Bowman-BirkTrypsin Inhibitor from Torresea cearensis Seeds. Biol. Chem. 1997, 378, 273-282. [CrossRef] [PubMed]

26. Rodrigues, R.F.; Tashima, A.K.; Pereira, R.M.S.; Mohamed, R.S.; Cabral, F.A. Coumarin solubility and extraction from emburana (Torresea cearensis) seeds with supercritical carbon dioxide. J. Supercrit. Fluids 2008, 43, 375-382. [CrossRef]

27. Kostova, I. Synthetic and natural coumarins as antioxidants. Mini Rev. Med. Chem. 2006, 6, 365-374. [CrossRef]

28. Fylaktakidou, K.; Hadjipavlou-Litina, D.; Litinas, K.; Nicolaides, D. Natural and Synthetic Coumarin Derivatives with Anti-Inflammatory/Antioxidant Activities. Curr. Pharm. Des. 2005, 10, 3813-3833. [CrossRef]

29. Gagliotti Vigil de Mello, S.V.; Frode, T.S. In Vitro and In Vivo Experimental Model-based Approaches for Investigating Anti-inflammatory Properties of Coumarins. Curr. Med. Chem. 2018, 25, 1446-1476. [CrossRef]

30. Stefanachi, A.; Leonetti, F.; Pisani, L.; Catto, M.; Carotti, A. Coumarin: A Natural, Privileged and Versatile Scaffold for Bioactive Compounds. Molecules 2018, 23, 250. [CrossRef]

31. Oliveira, M.T.A.; Moura, G.M.M.; da Cruz, J.I.O.; Lima, R.V.C.; dos Santos, E.A.; Andrade, J.C.; Alencar, M.V.O.B.; Landim, V.P.A.; Coutinho, H.D.M.; Uchoa, A.F. Serine protease inhibition and modulatory-antibiotic activity of the proteic extract and fractions from Amburana cearensis. Food Chem. Toxicol. 2020, 135, 110946. [CrossRef] [PubMed] 
32. Farias, D.F.; Cavalheiro, M.G.; Viana, M.P.; Queiroz, V.A.; Rocha-Bezerra, L.C.B.; Vasconcelos, I.M.; Morais, S.M.; Carvalho, A.F.U. Water extracts of Brazilian leguminous seeds as rich sources of larvicidal compounds against Aedes aegypti L. An. Acad. Bras. Cienc. 2010, 82, 585-594. [CrossRef] [PubMed]

33. Barberino, R.S.; Barros, V.R.P.; Menezes, V.G.; Santos, L.P.; Araújo, V.R.; Queiroz, M.A.A.; Almeida, J.R.G.S.; Palheta, R.C.; Matos, M.H.T. Amburana cearensis leaf extract maintains survival and promotes in vitro development of ovine secondary follicles. Zygote 2015, 24, 277-285. [CrossRef] [PubMed]

34. Gouveia, B.B.; Macedo, T.J.S.; Santos, J.M.S.; Barberino, R.S.; Menezes, V.G.; Müller, M.C.; Almeida, J.R.G.S.; Figueiredo, J.R.; Matos, M.H.T. Supplemented base medium containing Amburana cearensis associated with FSH improves in vitro development of isolated goat preantral follicles. Theriogenology 2016, 86, 1275-1284. [CrossRef] [PubMed]

35. Leal, L.; Fonseca, F.; Pereira, F.; Canuto, K.; Felipe, C.; Fontenele, J.; Pitombeira, M.; Silveira, E.; Viana, G. Protective Effects of Amburoside A, a Phenol Glucoside from Amburana cearensis, against CCl 4-Induced Hepatotoxicity in Rats. Planta Med. 2008, 74, 497-502. [CrossRef]

36. Leal, L.K.A.M.; Ferreira, A.A.G.; Bezerra, G.A.; Matos, F.J.A.; Viana, G.S.B. Antinociceptive, anti-inflammatory and bronchodilator activities of Brazilian medicinal plants containing coumarin: A comparative study. J. Ethnopharmacol. 2000, 70, 151-159. [CrossRef]

37. Leal, L.K.A.M.; Nechio, M.; Silveira, E.R.; Canuto, K.M.; Fontenele, J.B.; Ribeiro, R.A.; Viana, G.S.B. Anti-inflammatory and smooth muscle relaxant activities of the hydroalcoholic extract and chemical constituents from Amburana cearensis A.C. Smith. Phyther. Res. 2003, 17, 335-340. [CrossRef]

38. de Araújo Lopes, A.; Magalhães, T.R.; de Andrade Uchôa, D.E.; Silveira, E.R.; Azzolini, A.E.C.S.; Kabeya, L.M.; Lucisano-Valim, Y.M.; Vasconcelos, S.M.M.; de Barros Viana, G.S.; Leal, L.K.A.M. Afrormosin, an Isoflavonoid from Amburana cearensis A. C.; Smith, Modulates the Inflammatory Response of Stimulated Human Neutrophils. Basic Clin. Pharmacol. Toxicol. 2013, 113, 363-369. [CrossRef]

39. Hou, Y.; Dan, X.; Babbar, M.; Wei, Y.; Hasselbalch, S.G.; Croteau, D.L.; Bohr, V.A. Ageing as a risk factor for neurodegenerative disease. Nat. Rev. Neurol. 2019, 15, 565-581. [CrossRef]

40. Kritsilis, M.; Rizou, S.V.; Koutsoudaki, P.N.; Evangelou, K.; Gorgoulis, V.G.; Papadopoulos, D. Ageing, cellular senescence and neurodegenerative disease. Int. J. Mol. Sci. 2018, 19, 2937. [CrossRef]

41. Dorsey, E.R.; Sherer, T.; Okun, M.S.; Bloemd, B.R. The emerging evidence of the Parkinson pandemic. J. Parkinsons Dis. 2018, 8, S3-S8. [CrossRef] [PubMed]

42. Ray Dorsey, E.; Elbaz, A.; Nichols, E.; Abd-Allah, F.; Abdelalim, A.; Adsuar, J.C.; Ansha, M.G.; Brayne, C.; Choi, J.Y.J.; Collado-Mateo, D.; et al. Global, regional, and national burden of Parkinson's disease, 1990-2016: A systematic analysis for the Global Burden of Disease Study 2016. Lancet Neurol. 2018, 17, 939-953. [CrossRef]

43. Roger, V.L.; Go, A.S.; Lloyd-Jones, D.M.; Adams, R.J.; Berry, J.D.; Brown, T.M.; Carnethon, M.R.; Dai, S.; De Simone, G.; Ford, E.S.; et al. Heart disease and stroke statistics-2011 update: A report from the American Heart Association. Circulation 2011, 123, e18-e209. [CrossRef] [PubMed]

44. Ciccocioppo, F.; Bologna, G.; Ercolino, E.; Pierdomenico, L.; Simeone, P.; Lanuti, P.; Pieragostino, D.; Del Boccio, P.; Marchisio, M.; Miscia, S. Neurodegenerative diseases as proteinopathies-driven immune disorders. Neural Regen. Res. 2020, 15, 850-856.

45. Paris, I.; Cardenas, S.; Lozano, J.; Perez-Pastene, C.; Graumann, R.; Riveros, A.; Caviedes, P.; Segura-Aguilar, J. Aminochrome as a preclinical experimental model to study degeneration of dopaminergic neurons in Parkinson's disease. Neurotox. Res. 2007, 12, 125-134. [CrossRef]

46. Paris, I.; Lozano, J.; Perez-Pastene, C.; Muñoz, P.; Segura-Aguilar, J. Molecular and neurochemical mechanisms in PD pathogenesis. Neurotox. Res. 2009, 16, 271-279. [CrossRef]

47. Dickson, D.W. Neuropathology of Parkinson disease. Park. Relat. Disord. 2018, 46, S30-S33. [CrossRef]

48. Muñoz, P.; Cardenas, S.; Huenchuguala, S.; Bricen, A.; Couve, E.; Paris, I.; Segura-aguilar, J. DT-Diaphorase Prevents Aminochrome-Induced Alpha-Synuclein Oligomer Formation and Neurotoxicity. Toxicol. Sci. 2015, 145, 37-47. [CrossRef]

49. Muñoz, P.S.; Segura-Aguilar, J. DT-diaphorase Protects Against Autophagy Induced by Aminochrome-Dependent Alpha-Synuclein Oligomers. Neurotox. Res. 2017, 32, 362-367. [CrossRef]

50. Spillantini, M.G.; Schmidt, M.L.; Lee, V.M.Y.; Jakes, R.; Goedert, M. alpha-Synuclein in Lewy bodies. Nature 1997, 388, 839-840. [CrossRef] 
51. Hashimoto, M.; Rockenstein, E.; Crews, L.; Masliah, E. Role of protein aggregation in mitochondrial dysfunction and neurodegeneration in Alzheimer's and Parkinson's diseases. Neuromol. Med. 2003, 4, 21-36. [CrossRef]

52. Rocha, E.M.; De Miranda, B.; Sanders, L.H. Alpha-synuclein: Pathology, mitochondrial dysfunction and neuroinflammation in Parkinson's disease. Neurobiol. Dis. 2018, 109, 249-257. [CrossRef] [PubMed]

53. Hyman, B.T.; Van Hoesen, G.W.; Damasio, A.R. Alzheimer's disease: Glutamate depletion in the hippocampal perforant pathway zone. Ann. Neurol. 1987, 22, 37-40. [CrossRef] [PubMed]

54. Dugger, B.N.; Dickson, D.W. Pathology of neurodegenerative diseases. Cold Spring Harb. Perspect. Biol. 2017, 9, 1-22. [CrossRef]

55. Bondi, M.W.; Edmonds, E.C.; Salmon, D.P. Alzheimer's disease: Past, present, and future. J. Int. Neuropsychol. Soc. 2017, 23, 818-831. [CrossRef]

56. Xu, J.; Kao, S.-Y.; Lee, F.J.S.; Song, W.; Jin, L.-W.; Yankner, B.A. Dopamine-dependent neurotoxicity of $\alpha$ -synuclein: A mechanism for selective neurodegeneration in Parkinson disease. Nat. Med. 2002, 8, 600-606. [CrossRef]

57. Blum, D.; Torch, S.; Lambeng, N.; Nissou, M.; Michallon, C.H.U.; Pa, B.; Cedex, G. Molecular pathways involved in the neurotoxicity of 6-OHDA, dopamine and MPTP: Contribution to the apoptotic theory in Parkinson's disease. Prog. Neurobiol. 2001, 65, 135-172. [CrossRef]

58. Nunomura, A.; Perry, G.; Aliev, G.; Hirai, K.; Takeda, A.; Balraj, E.K.; Jones, P.K.; Ghanbari, H.; Wataya, T.; Shimohama, S.; et al. Oxidative Damage Is the Earliest Event in Alzheimer Oxidative damage is the earliest event in Alzheimer disease. J. Neuropathol. Exp. Neurol. 2001, 60, 759-767. [CrossRef]

59. Schapira, A.H.V.; Olanow, C.W.; Greenamyre, J.T.; Bezard, E. Slowing of neurodegeneration in Parkinson's disease and Huntington's disease: Future therapeutic perspectives. Lancet 2014, 384, 545-555. [CrossRef]

60. Wei, Z.; Li, X.; Li, X.; Liu, Q.; Cheng, Y. Oxidative Stress in Parkinson's Disease: A Systematic Review and Meta-Analysis. Front. Mol. Neurosci. 2018, 11, 236. [CrossRef]

61. Reeve, A.K.; Ludtmann, M.H.R.; Angelova, P.R.; Simcox, E.M.; Horrocks, M.H.; Klenerman, D.; Gandhi, S.; Turnbull, D.M.; Abramov, A.Y. Aggregated $\alpha$-synuclein and complex I deficiency: Exploration of their relationship in differentiated neurons. Cell Death Dis. 2015, 6, e1820. [CrossRef] [PubMed]

62. Sian, J.; Dexter, D.T.; Lees, A.J.; Daniel, S.; Agid, Y.; Javoy-agid, P.F.; Jenner, I.P.; Marsden, C.D.; Sian, J.; Dt, D.; et al. Alterations in Glutathione Levels in Padanson's Disease and Other Neurodegenerative Disorders Afecting Basal Ganglia. Ann. Neurol. 1994, 36, 348-355. [CrossRef] [PubMed]

63. Jenner, P.; Dexter, D.T.; Sian, J.; Schapira, A.H.V.; Marsden, C.D. Oxidative Stress as a Cause of Nigral Cell Death in Parkmson's Disease and Incidental Lewy Body Disease. Ann. Neurol. 1992, 32, S82-S87. [CrossRef] [PubMed]

64. Mosconi, L.; De Leon, M.; Murray, J.; Lez, E.; Lu, J.; Javier, E.; McHugh, P.; Swerdlow, R.H. Reduced mitochondria cytochrome oxidase activity in adult children of mothers with Alzheimer's disease. J. Alzheimer's Dis. 2011, 27, 483-490. [CrossRef]

65. Tramutola, A.; Lanzillotta, C.; Perluigi, M.; Butterfield, D.A. Oxidative stress, protein modification and Alzheimer disease. Brain Res. Bull. 2017, 133, 88-96. [CrossRef]

66. Xu, D.; Chen, H.; Mak, S.; Hu, S.; Tsim, K.W.K.; Hu, Y.; Sun, Y.; Zhang, G.; Wang, Y.; Zhang, Z.; et al. Neuroprotection against glutamate-induced excitotoxicity and induction of neurite outgrowth by T-006, a novel multifunctional derivative of tetramethylpyrazine in neuronal cell models. Neurochem. Int. 2016, 99, 194-205. [CrossRef]

67. Pallo, S.P.; Dimaio, J.; Cook, A.; Nilsson, B.; Johnson, G.V.W. Mechanisms of tau and A $\beta$-induced excitotoxicity. Brain Res. 2016, 1634, 119-131. [CrossRef]

68. Xing, C.; Arai, K.; Lo, E.H.; Hommel, M. Pathophysiologic cascades in ischemic stroke. Int. J. Stroke 2012, 7, 378-385. [CrossRef]

69. Dong, X.X.; Wang, Y.; Qin, Z.H. Molecular mechanisms of excitotoxicity and their relevance to pathogenesis of neurodegenerative diseases. Acta Pharmacol. Sin. 2009, 30, 379-387. [CrossRef]

70. Butt, A.M.; Vanzulli, I.; Papanikolaou, M.; De La Rocha, I.C.; Hawkins, V.E. Metabotropic Glutamate Receptors Protect Oligodendrocytes from Acute Ischemia in the Mouse Optic Nerve. Neurochem. Res. 2017, 42, 2468-2478. [CrossRef]

71. Berliocchi, L.; Bano, D.; Nicotera, P. Ca2+ signals and death programmes in neurons. Philos. Trans. R. Soc. Lond. B. Biol. Sci. 2005, 360, 2255-2258. [CrossRef] [PubMed] 
72. Azim, K.; Angonin, D.; Marcy, G.; Pieropan, F.; Rivera, A.; Donega, V.; Cantù, C.; Williams, G.; Berninger, B.; Butt, A.M.; et al. Pharmacogenomic identification of small molecules for lineage specific manipulation of subventricular zone germinal activity. PLoS Biol. 2017, 15, 1-27. [CrossRef] [PubMed]

73. Rueda, C.B.; Llorente-Folch, I.; Traba, J.; Amigo, I.; Gonzalez-Sanchez, P.; Contreras, L.; Juaristi, I.; Martinez-Valero, P.; Pardo, B.; del Arco, A.; et al. Glutamate excitotoxicity and $\mathrm{Ca}^{2+}$-regulation of respiration: Role of the $\mathrm{Ca}^{2+}$ activated mitochondrial transporters (CaMCs). Biochim. Biophys. Acta-Bioenerg. 2016, 1857, 1158-1166. [CrossRef] [PubMed]

74. Chassain, C.; Bielicki, G.; Donnat, J.-P.; Renou, J.-P.; Eschalier, A.; Durif, F. Cerebral glutamate metabolism in Parkinson's disease: An in vivo dynamic (13)C NMS study in the rat. Exp. Neurol. 2005, 191, 276-284. [CrossRef] [PubMed]

75. Pekny, M.; Wilhelmsson, U.; Tatlisumak, T.; Pekna, M. Astrocyte activation and reactive gliosis-A new target in stroke? Neurosci. Lett. 2019, 689, 45-55. [CrossRef] [PubMed]

76. Postolache, T.T.; Wadhawan, A.; Can, A.; Lowry, C.A.; Woodbury, M.; Makkar, H.; Hoisington, A.J.; Scott, A.J.; Potocki, E.; Benros, M.E.; et al. Inflammation in traumatic brain injury. J. Alzheimer's Dis. 2020, 74, 1-28. [CrossRef]

77. Kearney, H.; Cryan, J.; Beausang, A.; Looby, S.; Brett, F.M. Reactive gliosis mimicking tumor recurrence-A case series documenting MRI abnormalities and neuropathological correlates. Clin. Neuropathol. 2018, 37, 97-104. [CrossRef]

78. de Monasterio-Schrader, P.; Patzig, J.; Möbius, W.; Barrette, B.; Wagner, T.L.; Kusch, K.; Edgar, J.M.; Brophy, P.J.; Werner, H.B. Uncoupling of neuroinflammation from axonal degeneration in mice lacking the myelin protein tetraspanin-2. Glia 2013, 61, 1832-1847. [CrossRef]

79. Qin, L.; Liu, Y.; Cooper, C.; Liu, B.; Wilson, B.; Hong, J.S. Microglia enhance $\beta$-amyloid peptide-induced toxicity in cortical and mesencephalic neurons by producing reactive oxygen species. J. Neurochem. 2002, 83, 973-983. [CrossRef]

80. Kempuraj, D.; Thangavel, R.; Natteru, P.A.; Selvakumar, G.P.; Saeed, D.; Zahoor, H.; Zaheer, S.; Iyer, S.S.; Zaheer, A. Neuroinflammation Induces Neurodegeneration. J. Neurol. Neurosurg. Spine 2016, 1, 1003.

81. McGeer, P.L.; Itagaki, S.; Boyes, B.E.; McGeer, E.G. Reactive microglia are positive for HLA-DR in the substantia nigra of Parkinson's and Alzheimer's disease brains. Neurology 1988, 38, 1285 . [CrossRef] [PubMed]

82. Tang, Y.; Le, W. Differential Roles of M1 and M2 Microglia in Neurodegenerative Diseases. Mol. Neurobiol. 2016, 53, 1181-1194. [CrossRef] [PubMed]

83. Cherry, J.D.; Olschowka, J.A.; O'Banion, M.K. Neuroinflammation and M2 microglia: The good, the bad, and the inflamed. J. Neuroinflammation 2014, 11, 98. [CrossRef] [PubMed]

84. Chitnis, T.; Weiner, H.L. CNS inflammation and neurodegeneration. J. Clin. Investig. 2017, 127, 3577-3587. [CrossRef]

85. Sommer, A.; Winner, B.; Prots, I. The Trojan horse-Neuroinflammatory impact of T cells in neurodegenerative diseases. Mol. Neurodegener. 2017, 12, 1-10. [CrossRef]

86. Blasko, I.; Apochal, A.; Boeck, G.; Hartmann, T.; Grubeck-Loebenstein, B.; Ransmayr, G. Ibuprofen decreases cytokine-induced amyloid beta production in neuronal cells. Neurobiol. Dis. 2001, 8, 1094-1101. [CrossRef]

87. Bassani, T.B.; Vital, M.A.B.F.; Rauh, L.K. Neuroinflammation in the pathophysiology of Parkinson's disease and therapeutic evidence of anti-inflammatory drugs. Arq. Neuropsiquiatr. 2015, 73, 616-623. [CrossRef]

88. Tansey, M.G.; Goldberg, M.S. Neuroinflammation in Parkinson's disease: Its role in neuronal death and implications for therapeutic intervention. Neurobiol. Dis. 2010, 37, 510-518. [CrossRef]

89. Song, G.J.; Suk, K. Pharmacological modulation of functional phenotypes of microglia in neurodegenerative diseases. Front. Aging Neurosci. 2017, 9, 139. [CrossRef]

90. Spencer, J.P.E.; Vafeiadou, K.; Williams, R.J.; Vauzour, D. Neuroinflammation: Modulation by flavonoids and mechanisms of action. Mol. Asp. Med. 2012, 33, 83-97. [CrossRef]

91. Moon, Y.J.; Wang, X.; Morris, M.E. Dietary flavonoids: Effects on xenobiotic and carcinogen metabolism. Toxicol. In Vitro 2006, 20, 187-210. [CrossRef] [PubMed]

92. Costa, S.L.; Silva, V.D.A.; dos Santos Souza, C.; Santos, C.C.; Paris, I.; Muñoz, P.; Segura-Aguilar, J. Impact of Plant-Derived Flavonoids on Neurodegenerative Diseases. Neurotox. Res. 2016, 30, 41-52. [CrossRef] [PubMed] 
93. dos Santos Souza, C.; Grangeiro, M.S.; Lima Pereira, E.P.; dos Santos, C.C.; da Silva, A.B.; Sampaio, G.P.; Ribeiro Figueiredo, D.D.; David, J.M.; David, J.P.; da Silva, V.D.A.; et al. Agathisflavone, a flavonoid derived from Poincianella pyramidalis (Tul.), enhances neuronal population and protects against glutamate excitotoxicity. Neurotoxicology 2018, 65, 85-97. [CrossRef] [PubMed]

94. Trevisan, M.T.S.; Macedo, F.V.V.; Van De Meent, M.; Rhee, I.K.; Verpoorte, R. Seleção de plantas com atividade anticolinasterase para tratamento da doença de Alzheimer. Quim. Nova 2003, 26, 301-304. [CrossRef]

95. Knight, R.; Khondoker, M.; Magill, N.; Stewart, R.; Landau, S. A systematic review and meta-analysis of the effectiveness of acetylcholinesterase inhibitors and memantine in treating the cognitive symptoms of dementia. Dement. Geriatr. Cogn. Disord. 2018, 45, 131-151. [CrossRef]

96. Kamkwalala, A.R.; Newhouse, P.A. Beyond Acetylcholinesterase Inhibitors: Novel Cholinergic Treatments for Alzheimer's Disease. Curr. Alzheimer Res. 2017, 14, 377-392. [CrossRef]

97. Salari, S.; Bagheri, M. In vivo, in vitro and pharmacologic models of Parkinson's disease. Physiol. Res. 2019, 68, 17-24. [CrossRef]

98. Glinka, Y.; Gassen, M.; Youdim, M.B.H. Mechanism of 6-hydroxydopamine neurotoxicity. J. Neural Transm. Suppl. 1997, 50, 55-66.

99. Hernandez-Baltazar, D.; Zavala-Flores, L.M.; Villanueva-Olivo, A. El modelo de 6-hidroxidopamina y la fisiopatología parkinsoniana: Nuevos hallazgos en un viejo modelo. Neurologia 2017, 32, 533-539. [CrossRef]

100. Ghani, M.A.; Barril, C.; Bedgood, D.R.; Prenzler, P.D. Measurement of antioxidant activity with the thiobarbituric acid reactive substances assay. Food Chem. 2017, 230, 195-207. [CrossRef]

101. Sciacca, S.; Lynch, J.; Davagnanam, I.; Barker, R. Midbrain, pons, and medulla: Anatomy and syndromes. Radiographics 2019, 39, 1110-1125. [CrossRef] [PubMed]

102. Islam, M.T. Oxidative stress and mitochondrial dysfunction-linked neurodegenerative disorders. Neurol. Res. 2017, 39, 73-82. [CrossRef] [PubMed]

103. Wang, T.H.; Wang, S.Y.; Wang, X.D.; Jiang, H.Q.; Yang, Y.Q.; Wang, Y.; Cheng, J.L.; Zhang, C.T.; Liang, W.W.; Feng, H.L. Fisetin Exerts Antioxidant and Neuroprotective Effects in Multiple Mutant hSOD1 Models of Amyotrophic Lateral Sclerosis by Activating ERK. Neuroscience 2018, 379, 152-166. [CrossRef] [PubMed]

104. Paracatu, L.C.; Zeraik, M.L.; de Carvalho Bertozo, L.; de Andrade Bartolomeu, A.; da Silva Filho, L.C.; da Fonseca, L.M.; Ximenes, V.F. Synthesis, Antioxidant and Anti-inflammatory Properties of an Apocynin-Derived Dihydrocoumarin. Med. Chem. (Los. Angeles) 2016, 13, 93-100.

105. de Oliveira, N.K.S.; Almeida, M.R.S.; Pontes, F.M.M.; Barcelos, M.P.; de Paula da Silva, C.H.T.; Rosa, J.M.C.; Cruz, R.A.S.; da Silva Hage-Melim, L.I. Antioxidant Effect of Flavonoids Present in Euterpe oleracea Martius and Neurodegenerative Diseases: A Literature Review. Cent. Nerv. Syst. Agents Med. Chem. 2019, 19, 75-99. [CrossRef]

106. Hussein, R.M.; Mohamed, W.R.; Omar, H.A. A neuroprotective role of kaempferol against chlorpyrifos-induced oxidative stress and memory deficits in rats via GSK3 $\beta$-Nrf2 signaling pathway. Pestic. Biochem. Physiol. 2018, 152, 29-37. [CrossRef]

107. Cheng, X.; Yang, Y.L.; Yang, H.; Wang, Y.H.; Du, G.H. Kaempferol alleviates LPS-induced neuroinflammation and BBB dysfunction in mice via inhibiting HMGB1 release and down-regulating TLR4/MyD88 pathway. Int. Immunopharmacol. 2018, 56, 29-35. [CrossRef]

108. Roussaki, M.; Zelianaios, K.; Kavetsou, E.; Hamilakis, S.; Hadjipavlou-Litina, D.; Kontogiorgis, C.; Liargkova, T.; Detsi, A. Structural modifications of coumarin derivatives: Determination of antioxidant and lipoxygenase (LOX) inhibitory activity. Bioorganic Med. Chem. 2014, 22, 6586-6594. [CrossRef]

109. Hornedo-Ortega, R.; Cerezo, A.B.; de Pablos, R.M.; Krisa, S.; Richard, T.; García-Parrilla, M.C.; Troncoso, A.M. Phenolic compounds characteristic of the mediterranean diet in mitigating microglia-mediated neuroinflammation. Front. Cell. Neurosci. 2018, 12, 373. [CrossRef]

110. Beg, T.; Jyoti, S.; Naz, F.; Rahul; Ali, S.K.; Reyad, A.M.; Siddique, Y.H. Protective Effect of Kaempferol on the Transgenic Drosophila Model of Alzheimer's Disease. CNS Neurol. Disord.-Drug Targets 2018, 17, 421-429. [CrossRef]

111. Ahmad, A.; Ali, T.; Park, H.Y.; Badshah, H.; Rehman, S.U.; Kim, M.O. Neuroprotective Effect of Fisetin Against Amyloid-Beta-Induced Cognitive/Synaptic Dysfunction, Neuroinflammation, and Neurodegeneration in Adult Mice. Mol. Neurobiol. 2017, 54, 2269-2285. [CrossRef] [PubMed] 
112. Paulsen, B.S.; Souza, C.S.; Chicaybam, L.; Bonamino, M.H.; Bahia, M.; Costa, S.L.; Borges, H.L.; Rehen, S.K. Agathisflavone enhances retinoic acid-induced neurogenesis and its receptors $\alpha$ and $\beta$ in pluripotent stem cells. Stem Cells Dev. 2011, 20, 1711-1721. [CrossRef] [PubMed]

113. Chang, Y.; Lu, C.W.; Lin, T.Y.; Huang, S.K.; Wang, S.J. Baicalein, a Constituent of Scutellaria baicalensis, Reduces Glutamate Release and Protects Neuronal Cell Against Kainic Acid-Induced Excitotoxicity in Rats. Am. J. Chin. Med. 2016, 44, 943-962. [CrossRef] [PubMed]

114. Chang, C.Y.; Lin, T.Y.; Lu, C.W.; Huang, S.K.; Wang, Y.C.; Chou, S.S.P.; Wang, S.J. Hesperidin inhibits glutamate release and exerts neuroprotection against excitotoxicity induced by kainic acid in the hippocampus of rats. Neurotoxicology 2015, 50, 157-169. [CrossRef]

(C) 2020 by the authors. Licensee MDPI, Basel, Switzerland. This article is an open access article distributed under the terms and conditions of the Creative Commons Attribution (CC BY) license (http://creativecommons.org/licenses/by/4.0/). 